\title{
Survival and progression rates of anadromous brown trout kelts Salmo trutta during downstream migration in freshwater and at sea
}

\author{
Aarestrup, Kim; Baktoft, Henrik; Thorstad, EB; Svendsen, Jon Christian; Höjesjö, J; Koed, Anders
}

Published in:

Marine Ecology Progress Series

Link to article, DOI:

$10.3354 /$ meps 11407

Publication date:

2015

Document Version

Publisher's PDF, also known as Version of record

Link back to DTU Orbit

Citation (APA):

Aarestrup, K., Baktoft, H., Thorstad, EB., Svendsen, J. C., Höjesjö, J., \& Koed, A. (2015). Survival and progression rates of anadromous brown trout kelts Salmo trutta during downstream migration in freshwater and at sea. Marine Ecology Progress Series, 535, 185-195. https://doi.org/10.3354/meps 11407

\section{General rights}

Copyright and moral rights for the publications made accessible in the public portal are retained by the authors and/or other copyright owners and it is a condition of accessing publications that users recognise and abide by the legal requirements associated with these rights.

- Users may download and print one copy of any publication from the public portal for the purpose of private study or research.

- You may not further distribute the material or use it for any profit-making activity or commercial gain

- You may freely distribute the URL identifying the publication in the public portal 


\title{
Survival and progression rates of anadromous brown trout kelts Salmo trutta during downstream migration in freshwater and at sea
}

\author{
Kim Aarestrup ${ }^{1, *}$, Henrik Baktoft ${ }^{1}$, Eva B. Thorstad ${ }^{2}$, Jon C. Svendsen ${ }^{1,3}$, \\ Johan Höjesjö ${ }^{4}$, Anders Koed ${ }^{1}$ \\ ${ }^{1}$ National Institute of Aquatic Resources, Technical University of Denmark, Vejlsøvej 39, 8600 Silkeborg, Denmark \\ ${ }^{2}$ Norwegian Institute for Nature Research, 7485 Trondheim, Norway \\ ${ }^{3}$ Interdisciplinary Centre of Marine and Environmental Research, University of Porto, 4050-123 Porto, Portugal \\ ${ }^{4}$ Department of Biological and Environmental Sciences, University of Gothenburg, Box 463, 40530 Gothenburg, Sweden
}

\begin{abstract}
The marine migration of post-spawning anadromous fish remains poorly understood. The present study examined survival and progression rates of anadromous brown trout Salmo trutta L. after spawning (kelts) during downriver, fjord, and sea migration. Kelts $(\mathrm{n}=49)$ were captured in the Danish River Gudenaa, tagged with acoustic transmitters and subsequently recorded by automatic receivers. Kelts spent on average $25 \mathrm{~d}$ moving down the $45 \mathrm{~km}$ river and through the brackish fjord. The fish entered the Kattegat Sea between 14 April and 30 May. Eighteen of the 49 kelts disappeared in the river and fjord during outward migration, likely due to mortality. Survival was not significantly related to gill $\mathrm{Na}^{+} / \mathrm{K}^{+}$-ATPase activity, suggesting that physiological adaptation to saltwater may be less critical for adults compared to juveniles (smolts). Of the 31 fish that entered the Kattegat Sea, $45 \%$ survived and returned to the fjord. The duration of the entire marine migration, from leaving to entering the river, was on average $163 \mathrm{~d}$. The fish returned from the Kattegat Sea to the fjord between 22 July and 21 October. Upon return, the fish spent 1-90 d passing through Randers Fjord, with most individuals completing the reach within $4 \mathrm{~d}$, suggesting that the kelts spent limited time foraging after returning to the fjord. The total survival during the entire marine migration, including the fjord, was a minimum of $29 \%$. Our study provides data that are important for management of anadromous brown trout, and the high survival highlights that kelts may represent a valuable resource for both population reproduction and recreational fisheries.
\end{abstract}

KEY WORDS: Anadromous $\cdot$ Migration speed $\cdot$ Survival $\cdot$ Migration $\cdot$ Fishing mortality $\cdot$ Acoustic telemetry $\cdot$ Salmon $\cdot$ Swimming

Resale or republication not permitted without written consent of the publisher

\section{INTRODUCTION}

Brown trout Salmo trutta L. is an iteroparous species indigenous to Europe, North Africa and western Asia, and is also widely introduced to other parts of the world (Klemetsen et al. 2003). Populations with access to the sea usually have an anadromous component of the stock, termed sea trout. Sea trout is one of the most popular fishes among European anglers and, in many places, generates considerable income (Harris \& Milner 2007, Butler et al. 2009).

Sea trout typically migrate to sea as $1-5$ yr-old smolts. They achieve the majority of their somatic growth in marine waters, but always spawn in freshwater. Unlike most Pacific salmon, sea trout are iteroparous. Hence, after spawning, surviving adults, termed kelts, may return to sea to commence feeding, and can return to freshwater to spawn multiple 
times (Nall 1930). Repeat spawners can constitute a large proportion of spawning populations (L'Abeelund et al. 1989, Fournel et al. 1990, Aarestrup \& Jepsen 1998). These large repeat spawners are especially popular among anglers. They are also valuable to maintain population stability because they make a disproportionately large contribution to overall population gamete deposition and juvenile production, both because of their large size and because sea trout more often are females than males (Pemberton 1976a, Jensen et al. 2012).

The freshwater phase of brown trout migration has been subject to numerous studies (e.g. Svendsen et al. 2004, 2009, Thorstad et al. 2008); by contrast, the marine phase has received little interest (Drenner et al. 2012). The downstream smolt migration is regarded as a critical phase of their life history, since they face new predators and challenging physiological transformations to be able to migrate from freshto salt-water (Bendall et al. 2005, Aarestrup et al. 2014, del Villar-Guerra et al. 2014). The kelts undertake the same spatial migration as smolts and could also potentially be subject to high mortalities. With many wild sea trout populations in decline (ICES 2013), such losses may have a relatively large impact on the wild populations; hence, the marine environment is considered a priority area for sea trout research (Drenner et al. 2012).

Surprisingly little knowledge exists on kelt behaviour both during the final phase in freshwater and after entering the sea, particularly in relation to environmental conditions and the physiological status of the adult fish (Bendall et al. 2005). Basic data such as survival, migration timing, behaviour at sea, and time spent at sea are scarce (Bendall et al. 2005, Eldøy et al. 2015) and the lack of this fundamental information hampers proper management of sea trout fisheries. Consequently, the purpose of this 2 yr study was to estimate the survival and progression rates of sea trout kelts during downstream migration to the marine environment, time spent at sea, and survival of those returning to the same river system. This was done by capturing downstream migrating kelts in freshwater during spring and tagging them with acoustic transmitters, a method that has great potential for elucidating specific fish behaviour (Hussey et al. 2015). Their subsequent behaviour and survival were recorded and estimated by automatic listening stations deployed at different sites in the river and fjord. We tested whether survival and progression rates were affected by biotic and abiotic variables, such as tagging date, fish body size, condition factor, gill $\mathrm{Na}^{+} / \mathrm{K}^{+}$ATPase activity level, time of day and tidal cycle.

\section{MATERIALS AND METHODS}

\section{Study site}

The River Gudenaa (mean annual water discharge of $32 \mathrm{~m}^{3} \mathrm{~s}^{-1}$ ) is the major freshwater source to the narrow Randers Fjord. The River Lilleaa (mean annual water discharge of $2.6 \mathrm{~m}^{3} \mathrm{~s}^{-1}$ ) is the most important sea trout tributary (Aarestrup \& Jepsen 1998, Aarestrup et al. 2002) and drains into the River Gudenaa $15 \mathrm{~km}$ upstream from the fjord (Fig. 1). The $30 \mathrm{~km}$ long Randers Fjord is divided into 2 parts; a narrow inner section, and a wider outer section that exits into the Kattegat Sea. Study sites $(n=4)$ were situated along a stretch of the River Gudenaa and Randers Fjord, between the River Lilleaa tributary and the entrance to the Kattegat (Fig. 1). The salinity varies with water discharge in the River Gudenaa, but the fjord can be generally characterized as brackish, with increased salinity with increased depth and distance from the river mouth. Typical salinity values are approx. 5 ppt at Site 3 and 25 ppt at Site 4 .

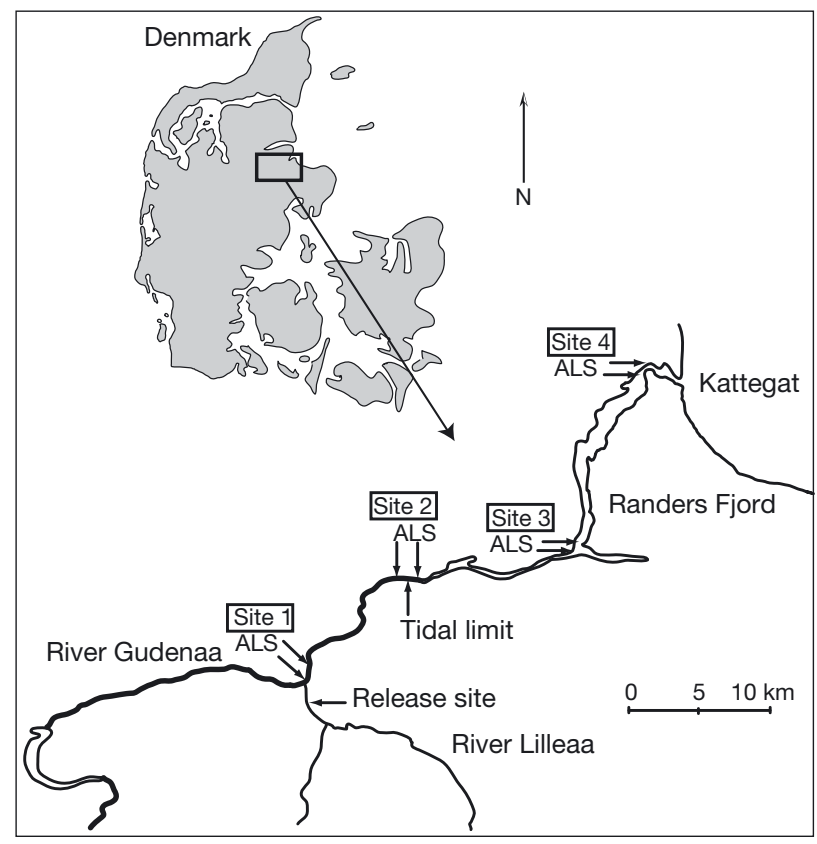

Fig. 1. Locations of the release site of sea trout kelts tagged with acoustic transmitters in the River Lilleaa, and Sites 1-4 comprising automatic listening stations (ALS) in the River Gudenaa and Randers Fjord, where tagged fish were recorded when passing. Site 1 is at the confluence between the Rivers Lilleaa and Gudenaa, Site 2 at the mouth of the River Gudenaa where it empties into the Randers Fjord, Site 3 separates the inner and outer Randers Fjord, and Site 4 is at the outer Randers Fjord where it exits into the Kattegat Sea 


\section{Capture, tagging and recording of the fish}

Downstream migrating kelts $(\mathrm{n}=49)$ were captured in the spring of 2004 and 2005 (Table 1) in a Wolf trap situated at Løjstrup Mill in the lower part of the River Lilleaa (Fig. 1). The fish were immediately tagged with individually coded model V8SC-2L acoustic transmitters (VEMCO) (outline dimensions = $9 \times 29 \mathrm{~mm}$, mass $=4.7$ and $2.9 \mathrm{~g}$ in air and water respectively, life-time $>294 \mathrm{~d}, 20-60$ nominal code delay, $146 \mathrm{~dB}$ power output) using the surgical implantation method described by Aarestrup et al. (1999). Total body length was measured to the nearest centimeter and body mass to the nearest gram. Sex was not determined because advanced silvering made it impossible to determine sex for most individuals by external characteristics. After recovery from anaesthesia and tagging, fish were immediately released back into the river below the trap. The largest transmitter-body mass ratio in air was $2.1 \%$.

While the fish was anaesthetised, a small gill biopsy (4 or 5 tips of gill filaments) was removed from the first gill arch of each fish and frozen in SEI buffer (300 mmol $\mathrm{l}^{-1}$ sucrose, $20 \mathrm{mmol} \mathrm{l^{-1 }} \mathrm{Na}$-EDTA, $50 \mathrm{mmol} \mathrm{l}^{-1}$ imidazole, $\mathrm{pH}$ 7.3) using a non-lethal gill biopsy method (McCormick 1993). This method is reported to have no effect on gill $\mathrm{Na}^{+} / \mathrm{K}^{+}$-ATPase activity (Rodgers et al. 1987), or on subsequent growth and survival of Atlantic salmon smolts (McCormick 1993), suggesting the same procedure will have little if any effect on the much larger sea trout kelts. $\mathrm{Na}^{+} / \mathrm{K}^{+}$-ATPase activity was analysed in gill homogenates at $27^{\circ} \mathrm{C}$ using the method described by (McCormick 1993), with a microtitre plate reader (Spectramax). Protein content in the tissue homogenates was measured using the Lowry method (Lowry et al. 1951), modified for the microtitre plate reader, i.e. reagent volumes being adjusted for 96well plates. Experiments were carried out subject to a licence (2012-DY-2934-00007) from the Animal Experimentation Inspectorate of the Danish Ministry of Justice.

Eight VR2 (VEMCO) automatic listening stations (ALS) were deployed in pairs at 4 sites in the river and fjord (Fig. 1), and were in operation until September 2006. Listening stations recorded and stored the individual code and time for tagged fish present within their range. The 2 ALSs moored at each site were separated by a few hundred meters in a longitudinal direction to optimise and confirm detection and overall swimming direction. Detection ranges of each ALS varied between 130 and $400 \mathrm{~m}$ during range tests, and the width of the river or fjord varied between 50 and $240 \mathrm{~m}$ at the ALS sites, which suggests that all tagged fish passing the ALS sites were recorded. Correspondingly, none of the fish recorded at outward sites had passed any inward site without being recorded, indicating estimated detection rates of $100 \%$ at Sites 1, 2 and 3. This estimation was not possible at Site 4, due to the lack of downstream ALSs, but a within-site estimation (number of fish detected at the outermost ALS at Site 4 also detected at the innermost ALS at Site 4) indicated equally high detection rate (estimated $100 \%$ at the innermost ALS at Site 4). These results indicate $100 \%$ detection efficiency at all sites as also indicated in previous studies (Aarestrup et al. 2010, 2014). The 4 groups of ALSs were placed $2.4 \mathrm{~km}$ (ALS 1), $17.3 \mathrm{~km}$ (ALS 2), $29.6 \mathrm{~km}$ (ALS 3) and $46.0 \mathrm{~km}$ (ALS 4) downstream from the release site (Fig. 1) to monitor the time of passage. This design enabled comparison of the survival and behaviour of kelts between 4 reaches, each with different physical characteristics: (1) the small River Lilleaa stretch from the release site to the confluence with the River Gudenaa $(2.4 \mathrm{~km}),(2)$ the $14.9 \mathrm{~km}$ stretch along the lower part of the River Gudenaa, (3) the $12.3 \mathrm{~km}$ narrow inner section of the Randers Fjord, and (4) the $16.3 \mathrm{~km}$ outer wider section of the Randers Fjord (Fig. 1). Calculation of progression rates were based on the first recording by the downstream ALS at each site, except in River Lilleaa where progression rates were calculated from the time of release to first registration in River Gudenaa. Manual acoustic tracking was performed using a VR60 receiver with omnidirectional hydrophone (VEMCO) by boat (downstream on the northern side and upstream on the southern side of the fjord) covering the entire inner and outer fjord in mid-June

Table 1. Mean body length $(\mathrm{cm})$ and body mass $(\mathrm{g})$ of tagged sea trout kelts (range in parentheses), and numbers that survived out of and returned back to Randers Fjord (percentage in parentheses) in the 2 study years

\begin{tabular}{|lccccc|}
\hline $\begin{array}{l}\text { Tagging } \\
\text { year }\end{array}$ & $\begin{array}{c}\text { Number of } \\
\text { fish tagged }\end{array}$ & $\begin{array}{c}\text { Length } \pm \text { SD } \\
\text { (range) }\end{array}$ & $\begin{array}{c}\text { Weight } \pm \text { SD } \\
\text { (range) }\end{array}$ & $\begin{array}{c}\text { Number exiting } \\
\text { the fjord }\end{array}$ & $\begin{array}{c}\text { Number } \\
\text { returning }\end{array}$ \\
\hline 2004 & 21 & $60 \pm 12.7(30-82)$ & $1901 \pm 1122(220-4225)$ & $17(81)$ & $7(33)$ \\
2005 & 28 & $57 \pm 14.0(31-87)$ & $1809 \pm 1356(225-5180)$ & $14(50)$ & $7(25)$ \\
\hline
\end{tabular}


2004 and 2005 to assess whether there were any remaining transmitters indicative of live or dead tagged fish in the area.

\section{Statistical analyses}

Survival to sea was analysed for potential correlations with body length, year, gill $\mathrm{Na}^{+} / \mathrm{K}^{+}$-ATPase activity, Fulton's condition factor $(K)$ and Day of Year of tagging using a binomial generalized linear model (GLM) with a logit link function following Zuur et al. (2013). The following model was fitted:

$$
\begin{aligned}
\text { Logit(survival) }= & \alpha+\text { length }+ \text { gill activity } \\
& + \text { year }+ \text { day }+K
\end{aligned}
$$

where $\alpha$ denotes a common intercept and the remaining terms represent the covariates of interest. Year was entered as a factor and the other terms as continuous. Model diagnostic showed no sign of under- or over-dispersion (dispersion statistic $=1.29$ ).

The probability of returning from the Kattegat Sea after leaving the fjord (using fish detected returning to Site 4 as criterion) was modelled using a binomial GLM with a logit link function following Zuur et al. (2013). The following model was fitted:

$$
\begin{aligned}
\text { Logit(return) }= & \alpha+\text { length }+ \text { gill-activity } \\
& + \text { year }+ \text { day }+K
\end{aligned}
$$

The dispersion statistic (1.14) indicated no over- or underdispersion.

Progression speeds in the 2 river and 2 fjord reaches of the 31 sea trout exiting to the Kattegat Sea were compared using linear mixed effects models following Zuur et al. (2009). We tested whether length, tagging date (Day of Year), year, and condition factor affected progression speed through the different reaches. Preliminary analysis revealed that data required $\log (x+0.01)$-transformation to meet model assumptions of homoscedasticity. Additionally, a variance structure allowing between-reach heterogeneity of variance was needed and therefore included. Thus, the following model was fitted:

$$
\begin{aligned}
& \log \left(\operatorname{speed}_{i j}+0.01\right)= \alpha+\text { comp }_{i j}+\text { length }_{i j} \\
&+ \text { gill activity }_{i j}+\text { year }_{i j} \\
&+ \text { day }_{i j}+K_{i j}+a_{i}+\varepsilon_{i j} \\
& a_{i} \sim \mathrm{N}\left(0_{i} \sigma_{a}^{2}\right) \\
& \varepsilon_{i j} \sim \mathrm{N}\left(0_{i} \sigma_{k}^{2}\right)
\end{aligned}
$$

Specifically, the $i$ observed progression speed of fish $j$ is modelled as the common intercept $\alpha$, the covariates (reach, length, gill activity, year, day of tagging and $K$ ), a random intercept $a_{i}$ (assumed to be normally distributed with mean 0 and variance $\sigma_{a}{ }^{2}$ ) and residuals $\varepsilon_{i j}$ (assumed to be normally distributed with mean of 0 and variance varying between reaches $k$, i.e. $\sigma_{k}^{2}$ ). Significance of each explanatory variable was tested using the Likelihood ratio (L-ratio) test using maximum likelihood estimation, whereas parameter estimates were obtained using restricted maximum likelihood estimation. Model diagnostic using residual plots showed no signs of violation of model assumptions.

Timing of migration to the sea (defined as first registration at Site 4) was related to the diel period and to the tidal cycle. In both cases, Watson's U2 test was applied to test whether the migration timing was uniformly distributed.

Statistical analyses were performed in R, v. 3.0.2 (R Core Team 2013) using the glm function of base package 'stats', the nlme package v. 3.1-111 (Pinheiro et al. 2013) and the 'circular' package v. 0.4-7 (Agostinelli \& Lund 2013).

\section{RESULTS}

\section{Survival}

In total, 31 of the 49 tagged sea trout survived the migration through the entire fjord and entered the Kattegat Sea (Tables $1 \& 2$ ). The survival was $81 \%$ in the first study year, and only $50 \%$ in the second study year, but the difference in survival between the years was not statistically significant $(p=0.107)$. Survival to sea was not related to gill $\mathrm{Na}^{+} / \mathrm{K}^{+}$-ATPase activity or tagging date (Table 3 ), but there was a non-significant positive effect of body length on survival $(\mathrm{p}=$ 0.103 ) (Fig. 2) and a marginally non-significant negative effect of condition factor $(p=0.053)$. The model explained ca. $20 \%$ of the variation in the data.

Throughout the system, sea trout were lost during the outward migration, with 1 individual lost in each reach in 2004. In 2005, 3 individuals were lost in the River Lilleaa, 2 in the River Gudenaa, 3 in the inner Randers Fjord, and 6 in the outer Randers Fjord. Overall, 8\% (4 of 49) of the tagged fish were lost in the River Lilleaa, 7 \% (3 of 45) in the River Gudenaa, $10 \%$ (4 of 42) in the inner Randers Fjord and 23\% (7 of 38) in the outer Randers Fjord (percentage loss for each reach is calculated as proportion of fish entering the reach). This corresponds to $3.5 \%$ loss km$~^{-1}$ in the River Lilleaa, $0.5 \%$ loss $\mathrm{km}^{-1}$ in the River Gudenaa, $0.8 \%$ loss $\mathrm{km}^{-1}$ in the inner fjord and $1.3 \%$ loss $\mathrm{km}^{-1}$ in the outer fjord. Thus, the Randers Fjord showed 
Table 2. Mean \pm SD time $(\mathrm{h})$ spent by tagged sea trout kelts in passing different reaches, and progression rates $\left(\mathrm{km} \mathrm{h}^{-1}\right)$ relative to the ground in the different reaches in the River Lilleaa, River Gudenaa and Randers Fjord for 2004, 2005, and both years combined. Range and number of individuals in each sample (n) are also shown

\begin{tabular}{|c|c|c|c|c|c|}
\hline & $\begin{array}{l}\text { Release to Site 1, } \\
\text { Gudenaa } \\
(2.7 \mathrm{~km})\end{array}$ & $\begin{array}{c}\text { Site } 1 \text { to } 2: \text { Gudenaa } \\
\text { to inner Randers } \\
(14.6 \mathrm{~km})\end{array}$ & $\begin{array}{l}\text { Site } 1 \text { to } 3: \text { Gudenaa } \\
\text { to entering outer } \\
\text { Randers }(26.9 \mathrm{~km})\end{array}$ & $\begin{array}{c}\text { Site } 1 \text { to } 4 \text { : Gudenaa } \\
\text { to entering Kattegat } \\
\qquad(43.3 \mathrm{~km})\end{array}$ & $\begin{array}{c}\text { Site } 2 \text { to } 4 \text { : Entering } \\
\text { inner Randers to entering } \\
\text { Kattegat }(28.7 \mathrm{~km})\end{array}$ \\
\hline \multicolumn{6}{|l|}{2004} \\
\hline \multicolumn{6}{|l|}{ Time } \\
\hline Mean $\pm \mathrm{SD}$ & $109 \pm 174$ & $162 \pm 227$ & $256 \pm 269$ & $616 \pm 195$ & $436 \pm 192$ \\
\hline Range & $4-530(\mathrm{n}=20)$ & $5-859(\mathrm{n}=19)$ & $14-947(\mathrm{n}=18)$ & $331-953(\mathrm{n}=17)$ & $94-734(\mathrm{n}=17)$ \\
\hline \multicolumn{6}{|c|}{ Progression rate } \\
\hline Mean $\pm \mathrm{SD}$ & $0.177 \pm 0.188$ & $0.920 \pm 1.138$ & $0.473 \pm 0.621$ & $0.079 \pm 0.029$ & $0.086 \pm 0.062$ \\
\hline Range & $0.005-0.620(\mathrm{n}=20)$ & $0.027-3.134(\mathrm{n}=19)$ & $0.044-1.914(\mathrm{n}=18)$ & $0.045-0.131(\mathrm{n}=17)$ & $0.039-0.306(\mathrm{n}=17)$ \\
\hline \multicolumn{6}{|l|}{2005} \\
\hline \multicolumn{6}{|l|}{ Time } \\
\hline Mean $\pm \mathrm{SD}$ & $132 \pm 169$ & $126 \pm 198$ & $172 \pm 208$ & $629 \pm 446$ & $464 \pm 292$ \\
\hline Range & $8-784(\mathrm{n}=25)$ & $5-757(\mathrm{n}=23)$ & $11-777(\mathrm{n}=20)$ & $88-1687(\mathrm{n}=14)$ & $84-930(\mathrm{n}=14)$ \\
\hline \multicolumn{6}{|c|}{ Progression rate } \\
\hline Mean $\pm \mathrm{SD}$ & $0.091 \pm 0.106$ & $1.175 \pm 1.272$ & $0.641 \pm 0.730$ & $0.152 \pm 0.164$ & $0.116 \pm 0.110$ \\
\hline Range & $0.003-0.337(\mathrm{n}=25)$ & $0.019-3.354(\mathrm{n}=23)$ & $0.035-2.553(\mathrm{n}=20)$ & $0.026-0.491(\mathrm{n}=14)$ & $0.031-0.342(\mathrm{n}=14)$ \\
\hline \multicolumn{6}{|l|}{$2004+2005$} \\
\hline \multicolumn{6}{|l|}{ Time } \\
\hline Mean $\pm \mathrm{SD}$ & $122 \pm 169$ & $142 \pm 210$ & $212 \pm 237$ & $622 \pm 59$ & $449 \pm 238$ \\
\hline Range & $4-784(\mathrm{n}=45)$ & $5-859(\mathrm{n}=42)$ & $11-947(\mathrm{n}=38)$ & 88-1687 (n = 31) & $84-930(n=31)$ \\
\hline \multicolumn{6}{|c|}{ Progression rate } \\
\hline Mean \pm SD & $0.129 \pm 0.106$ & $1.060 \pm 1.206$ & $0.562 \pm 0.677$ & $0.112 \pm 0.117$ & $0.099 \pm 0.087$ \\
\hline Range & $0.0034-0.620(\mathrm{n}=45)$ & $0.019-3.354(\mathrm{n}=42)$ & $0.035-2.553(\mathrm{n}=38)$ & $0.026-0.491(\mathrm{n}=31)$ & $0.031-0.342(\mathrm{n}=31)$ \\
\hline
\end{tabular}

Table 3. GLM modelling survival to sea as a function of length, year, gill-activity, tagging day and condition factor $(K)$. Parameter estimates are on the scale of the linear predictor

\begin{tabular}{|lrrrr|}
\hline & Estimate & SE & z-value & $\operatorname{Pr}(>|\mathrm{z}|)$ \\
\hline Intercept & 5.804 & 5.185 & 1.119 & 0.263 \\
Length & 0.052 & 0.032 & 1.630 & 0.103 \\
Year 2005 & -1.256 & 0.780 & -1.611 & 0.107 \\
Gill activity & 0.250 & 0.419 & 0.596 & 0.551 \\
Tag date & -0.020 & 0.026 & -0.753 & 0.452 \\
$K$ & -7.346 & 3.796 & -1.935 & 0.053 \\
\hline
\end{tabular}

the largest loss of tagged fish during the migration to the Kattegat Sea, both in absolute terms and relative to migration distance (if the short stretch in River Lilleaa is discounted). None of the lost sea trout were reported as captured by fishers. No transmitter was recorded during manual tracking in the Randers Fjord, indicating that no sea trout or transmitter was left in the fjord in mid-June.

Of the 31 fish that entered the Kattegat Sea, 14 (45\%) survived and returned to the Randers Fjord (Table 1). Survival in the Kattegat Sea was not related to year, body length, gill activity or day of

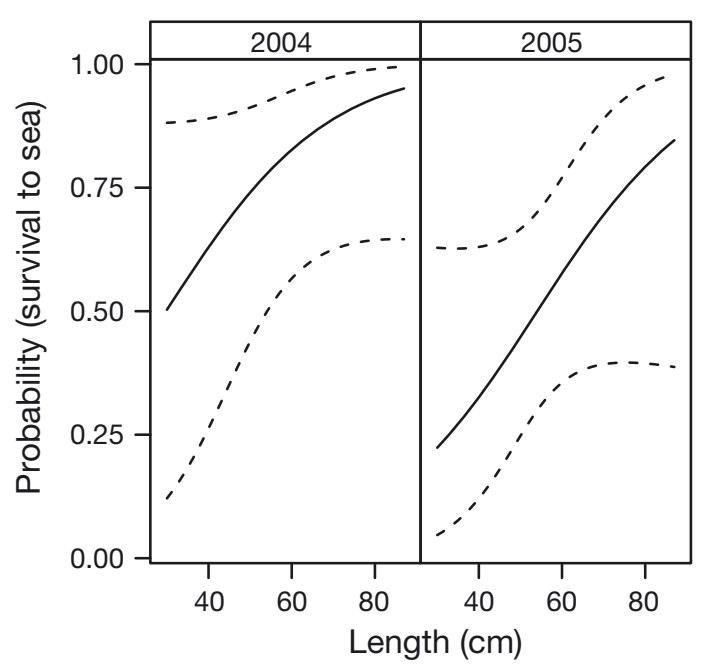

Fig. 2. Modelled effect of body length $( \pm 95 \%$ CI, dashed lines) on probability of survival from tagging in the River Lilleaa to reaching the Kattegat Sea in the 2 study years

tagging. Two more fish were lost in the Randers Fjord before return to the river. Hence, the total survival during the marine migration, from leaving to entering the River Gudenaa, was a minimum of $29 \%$ (12 of 42 sea trout). There were no significant effects 
Table 4. GLM modelling the probability of individuals returning as a function of length, year, gill-activity, tagging day and condition factor $(K)$. Parameter estimates are on the scale of the linear predictor

\begin{tabular}{|lrcrr|}
\hline & Estimate & SE & z-value & $\operatorname{Pr}(>|\mathrm{z}|)$ \\
\hline Intercept & 3.964 & 6.613 & 0.599 & 0.549 \\
Length & -0.031 & 0.035 & -0.897 & 0.370 \\
Year 2005 & 0.472 & 0.792 & 0.595 & 0.552 \\
Gill activity & -0.211 & 0.441 & -0.477 & 0.633 \\
Tag date & -0.012 & 0.033 & -0.367 & 0.714 \\
$K$ & -1.488 & 5.083 & -0.293 & 0.770 \\
\hline
\end{tabular}

of length, year, tagging date, condition or $\mathrm{Na}^{+} / \mathrm{K}^{+}$ATPase activity on survival back to the river (Table 4).

\section{Time spent at sea}

Fourteen fish entered the Kattegat Sea, where they remained, on average, for $120 \mathrm{~d}$ (range = 78-191 d, $\mathrm{SD}=32$ ). The first and last fish entered the Kattegat Sea on 14 April and 30 May, respectively, but with almost all trout entering within 3 wk from mid-April onwards (median date $=24$ April). The first fish returned from the Kattegat Sea to the fjord on 22 July and the last fish on 21 October (median date $=21$ August).

Considering the total time spent at sea, also including the brackish Randers Fjord, the trout spent on average 163 d (range 112-262 d, SD = 54) from leaving to entering the River Gudenaa. The first and last fish left the river on 20 March and 25 May, respectively (median date $=4$ April). The first fish returned to the river on 24 July and the last fish on 9 December (median date $=30$ August).

\section{Progression rates during migration}

The sea trout followed a unidirectional route out of the river and fjord, with no redetection at already passed sites, indicating none or little reversing of their migration route. The progression rates differed between reaches and were fastest in the inner fjord (L-ratio $=71.8, \mathrm{df}=3, \mathrm{p}<0.0001$ ) (Fig. 3), closely followed by River Gudenaa. Additionally, there was a rather weak but significant positive effect of both body length (L-ratio $=4.3, \mathrm{df}=1, \mathrm{p}=0.038$ ) and tagging date (L-ratio $=5.2, \mathrm{df}=1, \mathrm{p}=0.022$ ), whereas no effect of year (L-ratio $=0.1, \mathrm{df}=1, \mathrm{p}=0.72$ ) or condition factor (L-ratio $=0.037, \mathrm{df}=1, \mathrm{p}=0.85$ ) was observed (see Tables 5 \& 6).

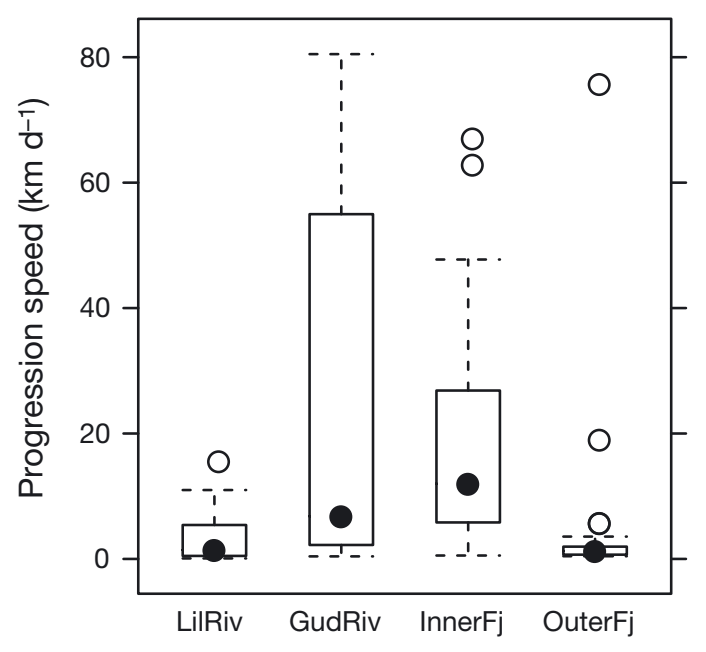

Fig. 3. Box-and-whisker plots showing progression rates relative to the ground in the 4 different reaches (LilRiv $=$ release site to the River Gudenaa confluence, GudRiv = lower part of the River Gudenaa, InnerFj = the narrow inner stretch of the Randers Fjord, OuterFj = the outer wider section of the fjord) for sea trout entering the Kattegat Sea $(n=31)$. Progression speed was fastest in the River Gudenaa and inner Randers Fjord and significantly slower in the River Lilleaa and outer Randers Fjord. Filled circles $=$ median values, box hinges $=$ interquartile ranges, whiskers $=1.5$ times the interquartile range, open circles $=$ data points outside this range

Table 5. Significance test of explanatory variables included in the linear mixed model analyzing progression speed. AIC is given for reference. L-ratio: Likelihood ratio

\begin{tabular}{|lccccc|}
\hline & df & AIC & LogLikelihood & L-ratio & $p$ \\
\hline Full model & 13 & 503.8 & -238.9 & - & - \\
Reach & 10 & 569.6 & -274.8 & 71.8 & $<0.0001$ \\
Tag date & 12 & 507.0 & -241.5 & 5.2 & 0.022 \\
Length & 12 & 506.1 & -241.0 & 4.3 & 0.038 \\
Year & 12 & 501.9 & -239.0 & 0.13 & 0.718 \\
$K$ & 12 & 501.8 & -238.9 & 0.037 & 0.846 \\
\hline
\end{tabular}

The sea trout stayed in the River Lilleaa for an average of $4.5 \mathrm{~d}$ before entering the River Gudenaa (i.e. passing Site 1) (Table 2), with $47 \%$ of the fish leaving this tributary within $2 \mathrm{~d}$. After entering the River Gudenaa (Site 1), the sea trout spent on average $6 \mathrm{~d}$ (range $=0.2-38 \mathrm{~d}, \mathrm{SD}=8.7$ ) before entering the Randers Fjord, and on average $19 \mathrm{~d}$ (range = 4-39 d, SD =9.9) before passing through the entire fjord and entering the Kattegat Sea (Table 2).

Upon return from the sea to the river, the fish spent on average $27 \mathrm{~d}$ (range $=1-90 \mathrm{~d}, \mathrm{SD}=34$ ) to pass the entire Randers Fjord. This corresponds to a migration speed of $0.33 \mathrm{~km} \mathrm{~h}^{-1}$ (range $=0.01-1.15 \mathrm{~km} \mathrm{~h}^{-1}, \mathrm{SD}=$ $0.4)$. 
Table 6. Summary of the mixed model analyzing progression speed. Model parameter estimates, associated SE, and $t$ test statistics and $p$-values. Response variable was $\log (x+0.01)-$ transformed. See Fig. 3 for definitions of the 4 reaches

\begin{tabular}{|lccccc|}
\hline & Value & $\mathrm{SE}$ & $\mathrm{df}$ & $t$-value & $\mathrm{p}$ \\
\hline Intercept & -4.793 & 1.276 & 105 & -3.757 & 0.0003 \\
Length & 0.015 & 0.007 & 39 & 2.064 & 0.046 \\
Tag date & 0.014 & 0.006 & 39 & 2.249 & 0.030 \\
Reach LilRiv & 0 & - & - & - & - \\
Reach GudRiv & 1.703 & 0.305 & 105 & 5.586 & $<0.0001$ \\
Reach InnerFj & 1.918 & 0.243 & 105 & 7.898 & $<0.0001$ \\
Reach OuterFj & 0.019 & 0.251 & 105 & 0.075 & 0.941 \\
Year 2004 & 0 & - & - & - & - \\
Year 2005 & -0.068 & 0.194 & 39 & -0.353 & 0.726 \\
$K$ & 0.192 & 1.072 & 39 & 0.179 & 0.859 \\
\hline
\end{tabular}

\section{Migration timing and tidal cycle}

The timing of diel migration differed significantly from random $(p<0.01)$, whereby fish predominantly entered the Kattegat Sea during the day and completely avoided entering the sea in the evening and the early part of the night. Furthermore, the majority of the sea trout entered the Kattegat Sea on the ebb tide $(\mathrm{p}<0.01)$ (Fig. 4).

\section{DISCUSSION}

\section{Survival}

Survival in the first year of this study $(81 \%)$ was similar to sea trout post-smolt survival previously recorded in the same fjord (79\%) (Aarestrup et al. 2014). By contrast, in the second study year, survival was considerably lower (50\%). D. Aldvén et al. (unpubl.) observed similar between-year variation on the west coast of Sweden, where survival of outmigrating kelts ranged between 40 and $95 \%$, whilst Bendall et al. (2005) found comparable survival (approx. $60 \%$ ) during migration to the coast of sea trout kelts tagged in the River Fowey, south-west England. The overall marine survival during the marine migration in the present study, from leaving to reentering the River Gudenaa, was higher (min. = $29 \%)$ than typically recorded for sea trout postsmolts during their first sea journey $(19,21$, and $15 \%$ observed by Gargan et al. 2006, Poole et al. 2006, and Jonsson \& Jonsson 2009, respectively). However, similar mean sea survival (33\%) was recorded for veteran migrants (fish that have performed earlier sea migrations) by Jonsson \& Jonsson (2009). Although survival rates at sea may vary considerably among years within the same study site (Poole et al. 2006, Jonsson \& Jonsson 2009), the generally higher survival of kelts than post-smolts may be caused by their larger size and hence fewer potential predators (Wootton 1998). The relatively high return rate of kelts as repeat spawners and their large size (and therefore large fecundity) suggest that kelts may provide an important input to population reproduction as well as for recreational fishery and should have high conservation priority in rivers especially where sea trout populations are endangered.

Due to the poor condition of some of the kelts, a condition-dependent mortality was expected, as recorded for rainbow trout Oncorhynchus mykiss (Keefer et al. 2008). However, models unexpectedly showed that fish with a lower condition factor had a marginally higher chance of survival to the Kattegat Sea. We have no explanation for this observa-
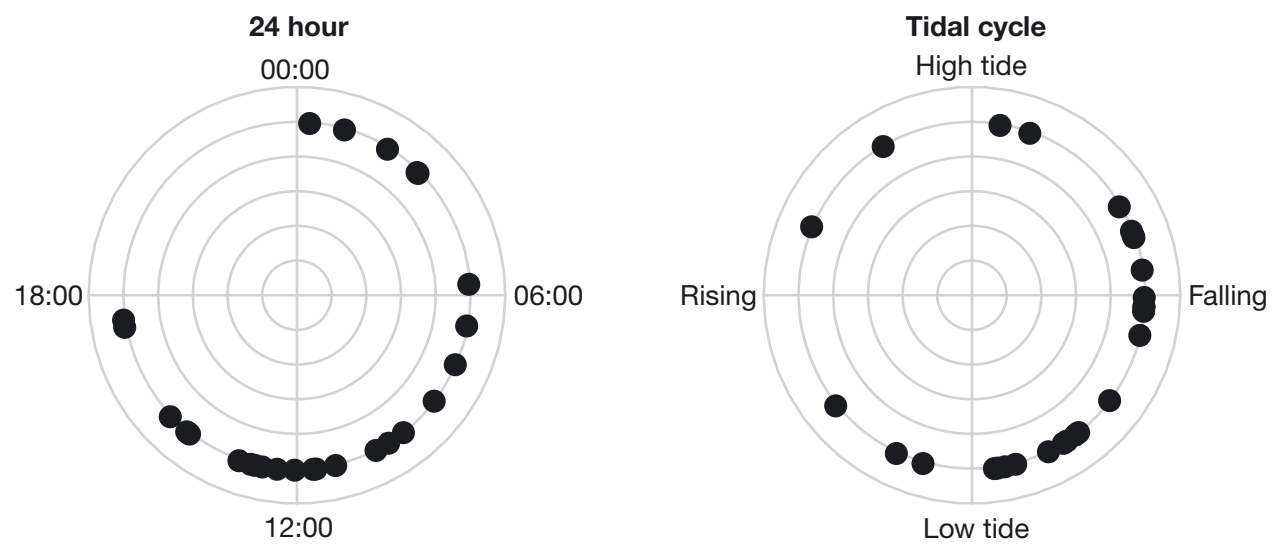

Fig. 4. Timing of the first registration of individual sea trout tagged with acoustic transmitters at Site 4 during their outward migration, relative to time of day (left panel) and tidal cycle (right panel 
tion, and the result may be an artefact due to the somewhat low number of tagged fish. We suggest that further studies should be performed to clarify this.

Gill $\mathrm{Na}^{+} / \mathrm{K}^{+}$-ATPase activity and tagging date did not affect survival, which is consistent with the findings of Bendall et al. (2005). Previous studies in juvenile salmonids have shown reduced survival and stunted growth in fish with low gill $\mathrm{Na}^{+} / \mathrm{K}^{+}$-ATPase activity (Duston 1994), and also a positive correlation between gill $\mathrm{Na}^{+} / \mathrm{K}^{+}$-ATPase activity and downstream movements in smolts (Aarestrup et al. 2000, Nielsen 2004). However, seawater tolerance may improve with increased body size (Tanguy et al. 1994), and Ugedal et al. (1998) found that half of the variation in seawater tolerance in hatchery-reared sea trout smolts was explained by fish size. Size effects may be attributable to a lesser surface areato-volume ratio of larger fish, and/or an increased osmo- and ion-regulatory capacity with body size. Therefore, the results of the present study support the fact that physiological adaptation to saltwater may be less important in sea trout kelts than in smolts and that kelts are already adapted to saltwater before exiting the river. However, potential size effects may also be lacking because of the relatively low salinity in the fjord, providing time for potential increase in gill $\mathrm{Na}^{+} / \mathrm{K}^{+}$-ATPase activity before entering the higher salinity Kattegat Sea

No tags were returned from fishers in the fjord. This was as expected because the tagged fish did not carry any external mark to enable their identification, and the transmitters had no reward label. Legal net fishing for sea trout in spring is also considerably smaller than in autumn, when a considerable proportion of acoustically tagged eels were caught by fishers in the same fjord (Aarestrup et al. 2008, 2010). However, reports of illegal fishing using monofilament nets for kelts in spring are known from the fjord. Angling for sea trout in the fjord is legal and common throughout the year, but with variable effort and capture rates. We cannot exclude the fact that the difference in survival between years may be partly caused by different fishing pressure in spring. Future studies may benefit from a more targeted approach to obtain estimates of fishing mortality in the fjord.

Since no transmitters were detected in the fjord during manual tracking in mid-June, and since the acoustic signals cannot be transmitted through air, the most plausible explanations for fish lost in the fjord without passing outward ALSs are that they were either preyed upon by mammalian or avian pis- civores capable of carrying the fish out of water, or caught by fishers who did not report the recapture. It is unlikely that the larger fish were removed from the fjord by predators, but the smaller fish may have fallen prey to various avian predators, including cormorants Phalacrocorax carbo, which are present in large numbers in the Randers Fjord (K. Aarestrup pers. obs.). This is supported by the observation of increased survival with increased body size of the kelts. Potential mammalian predators such as otter Lutra lutra and harbour seal Phoca vitulina would be able to prey upon even the largest fish, and both animals are common in the fjord (K. Aarestrup pers. obs.). Otters have been shown to prey heavily on riverine fish (Aarestrup et al. 2005), moving transmitters on land after a successful predation.

Potentially, there is a chance that some fish might have been lost due to transmitter dysfunction. However, these transmitters have previously proved to be reliable, and no tag failures after tags were started have been recorded during tests by the manufacturer (D. Webber pers. comm.). Transmitter dysfunction is therefore not a likely explanation for the loss of fish in the fjord.

\section{Time spent at sea}

Sea trout typically display marked variation in the timing and duration of the marine migration. Some fish return to freshwater in the autumn, following a few months at sea (Went 1962, Pratten \& Shearer 1983), and may regularly spend summers at sea and winters in freshwater, irrespective of their sexual maturity status (Berg \& Berg 1989). Similarly in the present study, a large proportion of the fish returned to the river during summer and autumn after a few months at sea. Usually all fish returning to Danish rivers during summer and autumn months are maturing; thus, all detected returning fish in this study are probably consecutive spawners ascending to reproduce. However, we cannot exclude the fact that fish returned from the Kattegat Sea, after the transmitters had depleted, as alternate spawners although they are suggested to be rare (Frier 1995). Additionally, fish may have strayed into other rivers. Hence, survival estimates are minimum estimates. Sea trout are frequently recorded in the sea during the winter months in many geographic areas (Pemberton 1976b, Svärdson \& Fagerström 1982, Jensen \& Rikardsen 2008) and a large coastal fishery by anglers during winter in Denmark also shows that at least in these more southern ranges, return to fresh- 
water is not obligatory. Time at sea recorded in the present study (78-191 d) was comparable to the results from the River Fowey (89-145 d) (Bendall et al. 2005). Sea residence time was shorter for sea trout from 2 different rivers in northern Norway, where the mean duration of stay at sea is $64-68 \mathrm{~d}$ (Berg \& Berg 1989, Jensen et al. 2014). This suggests that S.trutta exploit a considerably longer period of favourable growth conditions at sea in southern compared to northern areas.

\section{Progression rates during migration}

Bendall et al. (2005) recorded a short residency time for sea trout in the estuary during outward migration, with most fish leaving the estuary within 1 or 2 tidal cycles. In the present study, the fish spent a considerably longer time to migrate out to sea $($ mean $=26 \mathrm{~d})$. This difference is probably related to differences in the physical environment between the 2 systems, with much higher tidal amplitude and a shorter migratory distance in the River Fowey Estuary. The sea trout had a faster progression rate in the River Gudenaa and inner fjord than in the wider outer fjord. This progression pattern is similar to the observed pattern in postsmolts in the same system (Aarestrup et al. 2014). The faster progression in the river and inner fjord probably reflects the physical properties (narrow channels) providing higher downstream and outward current speeds compared to the outer fjord. The relatively slow progression rate in the outer fjord may indicate some foraging activity before exit to the Kattegat Sea. The outer fjord is wide and to some extent provides feeding habitat for sea trout, which is also indicated by the recreational angling throughout the year. The timing of fjord exit was consistent between the 2 study years, with most fish leaving the fjord at the end of April and early May, indicating this as an optimal time for entering the Kattegat Sea. This timing may explain the faster migration of later tagged fish, a pattern also observed in smolts (Moore et al. 1998).

The faster progression rate observed in the River Gudenaa compared to the River Lilleaa may be explained by the fish spending some time recovering after tagging and handling, or by the different physical properties of the 2 rivers. The fish lost in the River Lilleaa and River Gudenaa after release may have been caught by anglers or lost due to predation by otter or piscivorous predators such as pike Esox lucius. However, it is not possible to determine their exact fate because manual tracking of tagged fish was not performed in the river.

\section{Migration timing and tidal cycle}

Most sea trout exited the fjord on an ebbing tide, consistent with the pattern observed by Bendall et al. (2005). Despite the much lower tidal amplitude in Randers Fjord, current speeds at the outlet can be considerable, and it may be beneficial for the fish to leave with assistance of the outflowing current. Surprisingly, the sea trout predominantly left during daytime, and many individuals did so around noon. This is contrary to the pattern observed for other diadromous fishes, such as sea trout smolts (Aarestrup et al. 2014), and European eel Anguilla anguilla (Aarestrup et al. 2008, 2010) that have been recorded to leave the Randers Fjord mainly during the dark hours. We have no explanation for this pattern, but if nocturnal migration is related to predator avoidance (see Thorstad et al. 2008, Aldvén et al. 2015), large sea trout might experience less predation risk than sea trout smolts and European eel in this system and adjust their behaviour accordingly.

Downstream migration of sea trout kelts may occur over a relatively long period during winter and spring (Aarestrup \& Jepsen 1998). In the present study, we only tagged kelts during the last part of the downstream period. Potentially, these data do not reflect the behaviour and survival of earlier running fish. Similar studies over an extended time period would help to clarify this.

\section{Conclusion}

In conclusion, progression speed towards the sea was faster in the river and inner fjord, probably reflecting the physical properties of the study area. The timing of entrance into the Kattegat Sea was consistent with most fish leaving the fjord in late April and early May, indicating this period as the peak time for entering the Sea. Survival of sea trout kelts through the river and fjord, as well as the overall sea survival and return rate to the fjord and river, was relatively high. The majority of kelts are consecutive spawners, returning after a few months at sea. These repeat-spawner fish may make a disproportionate contribution to egg deposition due to their large body size and high survival. This underscores the potential value of kelts for endangered populations as well as for recreational fishing and should be a focus of future conservation strategies. 
Acknowledgements. This study was funded by the Danish rod and net fish license funds and the strategic project Salmon at Sea (SAS), financed by the Swedish Research Council (Formas).

\section{LITERATURE CITED}

Aarestrup K, Jepsen N (1998) Spawning migration of sea trout (Salmo trutta (L)) in a Danish river. Hydrobiologia 371-372:275-281

Aarestrup K, Jepsen N, Rasmussen G, Økland F (1999) Movements of two strains of radio tagged Altlantic salmon, Salmo salar L., smolts through a reservoir. Fish Manag Ecol 6:97-107

Aarestrup K, Nielsen C, Madsen SS (2000) Relationship between gill $\mathrm{Na}^{+}, \mathrm{K}^{+}$-ATPase activity and downstream movement in domesticated and first-generation offspring of wild anadromous brown trout (Salmo trutta). Can J Fish Aquat Sci 57:2086-2095

Aarestrup K, Nielsen C, Koed A (2002) Net ground speed of downstream migrating radio-tagged Atlantic salmon (Salmo salar L.) and brown trout (Salmo trutta L.) smolts in relation to environmental factors. Hydrobiologia 483: 95-102

Aarestrup K, Jepsen N, Koed A, Pedersen S (2005) Movement and mortality of stocked brown trout in a stream. J Fish Biol 66:721-728

Aarestrup K, Thorstad EB, Koed A, Jepsen N, and others (2008) Survival and behaviour of European silver eel in late freshwater and early marine phase during spring migration. Fish Manag Ecol 15:435-440

> Aarestrup K, Thorstad EB, Koed A, Svendsen JC, Jepsen N, Pedersen M, Økland F (2010) Survival and progression rates of large European silver eel Anguilla anguilla in late freshwater and early marine phases. Aquat Biol 9: 263-270

Aarestrup K, Baktoft H, Koed A, del Villar-Guerra D, Thorstad EB (2014) Comparison of the riverine and early marine migration behaviour and survival of wild and hatchery-reared sea trout Salmo trutta smolts. Mar Ecol Prog Ser 496:197-206

Agostinelli C, Lund U (2013) R package 'circular': Circular Statistics (v. 0.4-7). www.r-forge.r-project.org/projects/ circular (accessed 8 Jan 2015)

Aldvén D, Degerman E, Höjesjö J (2015) Environmental cues and downstream migration of anadromous brown trout (Salmo trutta) and Atlantic salmon (Salmo salar) smolts. Boreal Environ Res 20:35-44

Bendall B, Moore A, Quayle V (2005) The post-spawning movements of migratory brown trout Salmo trutta L. J Fish Biol 67:809-822

> Berg OK, Berg M (1989) The duration of sea and freshwater residence of the sea trout, Salmo trutta, from the Vardnes River in northern Norway. Environ Biol Fishes 24:23-32

> Butler JRA, Radford A, Riddington G, Laughton R (2009) Evaluating an ecosystem service provided by Atlantic salmon, sea trout and other fish species in the River Spey, Scotland: the economic impact of recreational rod fisheries. Fish Res 96:259-266

del Villar-Guerra D, Aarestrup K, Skov C, Koed A (2014) Marine migrations in anadromous brown trout (Salmo trutta). Fjord residency as a possible alternative in the continuum of migration to the open sea. Ecol Freshw Fish 23:594-603
Drenner SM, Clark TD, Whitney CK, Martins EG, Cooke SJ, Hinch SG (2012) A synthesis of tagging studies examining the behaviour and survival of anadromous salmonids in marine environments. PLoS ONE 7:e31311

> Duston J (1994) Effect of salinity on survival and growth of Atlantic salmon (Salmo salar) parr and smolts. Aquaculture 121:115-124

- Eldøy SH, Davidsen JG, Thorstad EB, Whoriskey F and others (2015) Marine migration and habitat use of anadromous brown trout (Salmo trutta). Can J Fish Aquat Sci doi:10.1139/cjfas-2014-0560

Fournel F, Euzenat G, Fagard J (1990) Evaluation des taux de recapture et de retour de la truite de mer sur le bassin de la Bresle (Haute-Normandie/Picardie). Bull Français la Pêche La Piscic 318:102-114 (in French)

Frier JO (1995) Limfjordens ørredbestand, 1: tilstand og udviklingsmuligheder. IFF report 44, Institut for Ferskvandsfiskeri og Fiskepleje. Aalborg Universitetsforlag, Aalborg (in Danish)

Gargan P, Roche W, Forde G, Ferguson A (2006) Characteristics of the sea trout (Salmo trutta L.) stocks from the Owengowla and Invermore fisheries, Connemara, Western Ireland, and recent trends in marine survival. In: Harris G, Milner N (eds) Sea trout: biology, conservation and management. Blackwell, Oxford, p 60-75

Harris G, Milner N (eds) (2007) Sea trout: biology, conservation and management. Blackwell, Oxford

> Hussey NE, Kessel ST, Aarestrup K, Cooke SJ, and others (2015) Aquatic animal telemetry: a panoramic window into the underwater world. Science 348:6240

ICES (2013) Report of the Baltic salmon and trout assessment working group (WG BEST). ICES Advisory Committee, Tallinn

Jensen AJ, Finstad B, Fiske P, Hvidsten NA, Rikardsen AH, Saksgård L, Bradford M (2012) Timing of smolt migration in sympatric populations of Atlantic salmon (Salmo salar), brown trout (Salmo trutta), and Arctic char (Salvelinus alpinus). Can J Fish Aquat Sci 69:711-723

Jensen JLA, Rikardsen AH (2008) Do northern riverine anadromous Arctic charr Salvelinus alpinus and sea trout Salmo trutta overwinter in estuarine and marine waters? J Fish Biol 73:1810-1818

> Jensen JLA, Rikardsen AH, Thorstad EB, Suhr AH, Davidsen JG, Primicerio R (2014) Water temperatures influence the marine area use of Salvelinus alpinus and Salmo trutta. J Fish Biol 84:1640-1653

Jonsson B, Jonsson N (2009) Migratory timing, marine survival and growth of anadromous brown trout Salmo trutta in the River Imsa, Norway. J Fish Biol 74:621-638

Keefer ML, Wertheimer RH, Evans AF, Boggs CT, Peery CA (2008) Iteroparity in Columbia River summer-run steelhead (Oncorhynchus mykiss): implications for conservation. Can J Fish Aquat Sci 65:2592-2605

Klemetsen A, Amundsen PA, Dempson J, Jonsson B, Jonsson N, O'Connell MF, Mortensen E (2003) Atlantic salmon Salmo salar L., brown trout Salmo trutta L. and Arctic charr Salvelinus alpinus (L.): a review of aspects of their life histories. Ecol Freshw Fish 12:1-59

L'Abee-lund JH, Jonsson B, Jensen AJ, Saettem LM, Heggberget TG, Johnsen BO, Naesje TF (1989) Latitudinal variation in life-history characteristics of sea-run migrants brown trout Salmo trutta. J Anim Ecol 58:525-542

> Lowry OH, Rosebrough NJ, Farr AL, Randall RJ (1951) Protein measurement with the folin phenol reagent. J Biol Chem 193:265-275 
McCormick SD (1993) Methods for nonlethal gill biopsy and measurement of $\mathrm{Na}^{+}, \mathrm{K}^{+}$-ATPase activity. Can J Fish Aquat Sci 50:656-658

Moore A, Ives M, Scott M, Bamber S (1998) The migratory behaviour of wild sea trout (Salmo trutta L.) smolts in the estuary of the River Conwy, North Wales. Aquaculture 168:57-68

Nall G (1930) The life of the sea trout. Seeley, Service \& Co, London

Nielsen C (2004) Future migratory behaviour predicted from premigratory levels of gill $\mathrm{Na}^{+} / \mathrm{K}^{+}$-ATPase activity in individual wild brown trout (Salmo trutta). J Exp Biol 207:527-533

Pemberton R (1976a) Sea trout in North Argyll sea lochs: II. diet. J Fish Biol 9:195-208

Pemberton R (1976b) Sea trout in North Argyll Sea lochs, population, distribution and movements. J Fish Biol 9: 157-179

Pinheiro J, Bates D, DebRoy S, Sarkar D, R Core Team (2013) nlme: linear and nonlinear mixed effects models. $\mathrm{R}$ package version 3.1-111

Poole W, Dillane M, DeEyto E, Rogan G, McGinnity P, Whelan K (2006) Characteristics of the Burrishoole sea trout population: census, marine survival, enhancement and stock recruitment relationship, 1971-2003. In: Harris G, Milner N (eds) Sea trout: biology, conservation and management. Blackwell, Oxford, p 107-114

Pratten DJ, Shearer WM (1983) Sea trout of the North Esk. Aquac Res 14:49-65

R Core Team (2013) R: a language and environment for statistical computing. R Foundation for Statistical Computing, Vienna. www.r-project.org

Rodgers JD, Ewing RD, Hall JD (1987) Physiological changes during seaward migration of wild juvenile coho salmon

Editorial responsibility: Alejandro Gallego,

Aberdeen, UK
(Oncorhynchus kisutch). Can J Fish Aquat Sci 44:452-457

Svärdson G, Fagerström Å (1982) Adaptive difference in the long-distance migration of some trout (Salmo trutta L.) stocks. Report Vol. 60. Institute of Freshwater Research, Drottningholm, p 58-80

Svendsen J, Koed A, Aarestrup K (2004) Factors influencing the spawning migration of female anadromous brown trout. J Fish Biol 64:528-540

Svendsen JC, Aarestrup K, Dolby J, Svendsen TC, Christensen RHB (2009) The volitional travel speed varies with reproductive state in mature female brown trout Salmo trutta. J Fish Biol 75:901-907

Tanguy J, Ombredane D, Bagliniere J, Prunet P (1994) Aspects of parr-smolt transformation in anadromous and resident forms of brown trout (Salmo trutta) in comparison with Atlantic salmon (Salmo salar). Aquaculture 121: 51-63

- Thorstad EB, Økland F, Aarestrup K, Heggberget TG (2008) Factors affecting the within-river spawning migration of Atlantic salmon, with emphasis on human impacts. Rev Fish Biol Fish 18:345-371

Ugedal O, Finstad B, Damsgård B, Mortensen A (1998) Seawater tolerance and downstream migration in hatcheryreared and wild brown trout. Aquaculture 168:395-405

Went AEJ (1962) Irish sea trout, a review of investigations to date. Sci Proc R Dublin Soc 1:265-298

Wootton RJ (1998) Ecology of teleost fishes, 2nd edn. Kluwer Academic Publishers, Dordrecht

Zuur AF, Ieno EN, Walker NJ, Saveliev AA, Smith GM (2009) Mixed effects models and extensions in ecology with R. Springer, New York, NY

Zuur AF, Hilbe JM, Ieno EN (2013) A beginner's guide to GLM and GLMM with R. A frequentist and Bayesian perspective for ecologists. Highland Statistics, Newburgh

Submitted: January 13, 2015; Accepted: June 29, 2015 Proofs received from author(s): August 21, 2015 